\title{
Vegetable consumption and blood lead concentrations
}

\author{
J E J GALLACHER, ${ }^{1}$ P C ELWOOD, ${ }^{1}$ KARIN M PHILLIPS, ${ }^{1}$ B E DAVIES, ${ }^{2}$ R C \\ GINNEVER, ${ }^{2}$ C TOOTHILL, ${ }^{3}$ AND D T JONES 4 \\ From the Medical Research Council Epidemiology Unit (South Wales), ${ }^{1}$ Cardiff CF2 3AS, the Department of \\ Geography, ${ }^{2}$ University of Wales, Aberystwyth, the Supra-Regional Assay Service, ${ }^{3}$ Leeds, and Clwyd Health \\ Authority, ${ }^{4}$ Mold, UK
}

SUMMARY Women resident in an area heavily contaminated by spoil from old lead mining have blood lead concentrations that are about $50 \%$ higher $(\mathrm{p}<0.001)$ than those of women living in a "control" area some distance away. Blood lead concentrations were related to the consumption of home grown produce. Those with the highest consumptions had blood lead concentrations that were $28 \%$ higher $(\mathrm{p}<0.001)$ than those of women who consumed no locally grown vegetables. Nevertheless, in the total population in the area this effect seemed likely to account for only about $5 \%$ of the population mean blood lead concentration. The data suggested that an increase in soil lead of $1000 \mu \mathrm{g} / \mathrm{g}$ is associated with an increase in blood lead of about $0 \cdot 20 \mu \mathrm{M} / 1(4 \cdot 2 \mu \mathrm{g} / \mathrm{dl})$.

The determinants of blood lead have not been adequately quantified in any population, but it is generally agreed that in the United Kingdom a major contribution comes from food. ${ }^{1-3}$ Chamberlain estimated that around $0.5 \%$ of dietary lead can be attributed to animal products and $16 \%$ to foliar uptake by plants from the atmosphere. ${ }^{4}$ Whereas only a small proportion of lead absorbed by plant roots is transported to the shoots and other edible portions $^{5}$ about $13 \%$ of dietary lead has been attributed to root vegetables. ${ }^{2}$

The major limitation in the evidence is data relating food lead to body lead. To obtain direct evidence on this pathway a study was conducted in which vegetable consumption and blood lead concentrations were examined in an area with high soil lead concentrations.

\section{Subjects, area, and methods}

The work was based on villages on the Halkyn Mountain, in Clwyd, North Wales. This is a carboniferous limestone outcrop, mineralised by galena $(\mathrm{PbS})$ and sphalerite $(\mathrm{ZnS})$, and it was the centre of an active lead mining industry until the middle years of this century. The whole area is now heavily contaminated by lead spoil. Davies and Roberts showed that there were $171 \mathrm{~km}^{2}$ of contaminated soils with over $100 \mu \mathrm{g} \mathrm{Pb} / \mathrm{g}$ soil, and 44 $\mathrm{km}^{2}$ of heavily contaminated soil (1000 to $10000 \mu \mathrm{g}$ $\mathrm{Pb} / \mathrm{g}$ soil, or higher). ${ }^{6}$ Davies and White subsequently reported that vegetables and salad crops grown on these soils could accumulate lead in excess of the present British legal limit for lead in food $(1 \mu \mathrm{g} / \mathrm{g}$ fresh weight), ${ }^{7}$ and they speculated that this might present a public health risk. ${ }^{8}$ A village about $30 \mathrm{~km}$ west of this area was used as a "control" area. This is built on Silurian shales with soil lead concentrations generally below $100 \mu \mathrm{g} \mathrm{Pb} / \mathrm{g}$ soil and is remote from industry and from lead mining.

A preliminary census was conducted in the villages in the contaminated area and in the control village. All children aged 1-3 years and their mothers were identified. Several studies were based on the children, including an investigation of pica, hand lead, and blood lead ${ }^{9}$ but in this paper we report only the blood lead concentrations of the mothers. They were questioned about their consumption of locally grown vegetables, salad crops, and fruit. They were grouped at three levels - those who ate little or no vegetables grown at home ("none" in what follows), those who usually consumed some home grown produce ("some"), and those who consumed mostly home grown vegetables ("most").

In the lead contaminated area we supplemented the sample of mothers with a stratified random sample of women drawn from the electoral roll. This was achieved as follows: all the women on the electoral rolls for the villages were visited and questioned about their consumption of vegetables etc. A stratified sample was then drawn with $\mathbf{3 0}$ women in each of the two groups with the lower levels 
of consumption and 50 women in the group with the highest intakes.

A venous blood sample was taken from each woman, and a sample of soil was taken from their garden; about $1 \mathrm{~kg}$ of topsoil was taken with a stainless steel trowel from the top $15 \mathrm{~cm}$ of the vegetable plot or from a bed where vegetables might be grown. Air samples were taken $(4.5 \mathrm{l} / \mathrm{min}$ for seven consecutive days) in the dwellings of a subsample of the women in each area. The sampling head was placed at about one metre above the floor, in the living room or kitchen. A "random day-time" sample of water was also taken from the cold kitchen tap in a subsample of dwellings.

Estimations of blood lead were made by atomic absorption spectrophotometry at the Leeds Supra-Regional Assay Service Laboratory. The soil samples were air dried, disaggregated, and passed through a nylon sieve of $2 \mathrm{~mm}$ aperture. Lead was extracted by hot, concentrated nitric acid and determined by flame atomic absorption spectrophotometry. Water samples were acidified before lead analysis.

As the lead concentrations in soil, air, and water were appreciably skewed these were transformed before analysis. To obtain group measurements for the soil and air samples the logarithms of the original readings were used; for the water sample the cube roots of the original readings were used.

\section{Results}

The villages on which this work was based are all rural. Traffic flow was estimated to be under 500 vehicles a day in the control village and only slightly higher than this in the villages in the contaminated area. Indoor air lead concentrations were measured in the main living rooms or kitchens of representative samples of dwellings throughout the areas, and random day time samples of water were taken from the cold kitchen taps of dwellings. The results (table 1) confirm that apart from soil in the old lead mining area environmental lead concentrations are low in both areas.

Table 2 displays the numbers of subjects in the various population samples, subdivided by their consumption of locally grown vegetables. Compliance was high and the numbers for whom soil and blood lead data were obtained are around $90 \%$ of the total samples drawn.

A preliminary analysis of data from the two samples of women in the contaminated area (the mothers of young children and the random sample of female electors) showed that within the subgroups defined by vegetable consumption there was no evidence of significant heterogeneity in either blood
Table 1 Environmental lead concentrations. Estimates of soil lead and indoor air lead (based on log transformations) and water lead (based on cube root transformation) in the two areas. Measurements made in the dwellings and gardens of a subsample of the total population surveyed

\begin{tabular}{lll}
\hline & Contaminated area & Control area \\
\hline Soil lead $(\mu \mathrm{g} / \mathrm{g}):$ & & \\
$\quad$ Mean & 1009 & 79 \\
$95 \%$ Range & $143-7123$ & $22-283$ \\
No & 143 & 33 \\
Indoor air lead $\left(\mu \mathrm{g} / \mathrm{M}^{3}\right):$ & & \\
Mean & 0.07 & 0.04 \\
Actual range & $0.04-0.21$ & $0.01-0.13$ \\
No & 12 & 9 \\
Water lead (mg/l): & 0.004 & 0.003 \\
Mean & $0-0.026$ & $0-0.021$ \\
95\% Range & 52 & 28 \\
No & & \\
\hline
\end{tabular}

Table 2 Details of the vegetable consumption by population samples. (Figures in parentheses are numbers who cooperated)

\begin{tabular}{lllll}
\hline & \multicolumn{4}{l}{ Consumption of locally grown vegetables } \\
\cline { 2 - 5 } Sample of women & None & Some & Most & Totals \\
\hline Lead contaminated area: & & & & \\
$\quad$ Total No of women in villages & 525 & 73 & 75 & 673 \\
Random sample of women & $30(26)$ & $30(25)$ & $50(41)$ & $110(92)$ \\
Mothers of young children $_{\text {Total }}^{*}$ & $44(36)$ & $12(12)$ & $11(10)$ & $67(58)$ \\
Control area & 59 & 33 & 46 & 138 \\
& $23(20)$ & $8(7)$ & $6(6)$ & $37(33)$
\end{tabular}

*These are not necessarily the sum of the random sample plus the mothers as some mothers had been drawn in the random sample.

lead concentrations or the soil lead concentrations in their gardens. The data for the two samples are therefore amalgamated in what follows.

Table 3 shows the mean and range of the soil lead concentrations in the two areas. There is a highly significant difference between the soil lead concentrations in the contaminated and the control areas, but within each area concentrations in the gardens of the three subsamples of women are homogeneous.

Table 4 displays the mean blood lead concentrations in the various subsamples of women defined by their consumption of locally grown vegetables etc. An estimate is also given of the mean blood lead of the total adult female populations in the two areas. In the contaminated villages the mean for the sample of mothers $(0.57 \pm 0.03 \mu \mathrm{M} / 1)$ is identical to a mean concentration derived from the random sample of women, weighted to allow for stratification $(0.57 \pm 0.02 \mu \mathrm{M} / 1)$. These means, however, are $50 \%$ higher $(\mathrm{p}<0.001)$ than the mean blood lead concentrations in the control village. Putting this difference in mean blood lead concentration $(0.19 \mu \mathrm{M} / \mathrm{l})$ together with the 
Table 3 Soil lead by vegetable consumption. Mean soil lead concentrations ( $\mu \mathrm{g} / \mathrm{g}$ ) with ranges (shown as $95 \%$ confidence limits) in the gardens of the various population subgroups. (Numbers shown in table 1)

\begin{tabular}{llll}
\hline Consumption of home grown vegetables & Nome & Some & Most \\
\hline $\begin{array}{l}\text { Lead contaminated area: } \\
\text { Mean }\end{array}$ & 1009 & 1069 & 964 \\
Range & $131-7761$ & $120-9498$ & $181-5142$ \\
Control area: & 85 & 75 & 66 \\
$\quad$ Sample of mothers & $26-273$ & $12-472$ & $25-175$ \\
Range & & & \\
\hline
\end{tabular}

All group measurements were obtained after taking the logarithm of the original measurements.

Table 4 Blood lead concentrations by vegetable consumption in population groups. Mean blood lead concentrations $(\mu M / l)$ (with $S D s)$ in the various population subgroups, together with estimated mean concentrations for the total populations, weighted to allow for stratification (table 1)

\begin{tabular}{lcccc}
\hline Consumption of home grown vegetables & None & Some & Most & $\begin{array}{l}\text { All } \\
\text { women }\end{array}$ \\
\hline Lead contaminated area & 0.54 & 0.62 & 0.69 & 0.57 \\
Control area & $(0.22)$ & $(0.18)$ & $(0.23)$ & $(0.25)$ \\
& 0.38 & 0.35 & 0.40 & 0.38 \\
& $(0.10)$ & $(0.08)$ & $(0.08)$ & $(0.09)$ \\
\hline
\end{tabular}

Estimate of the population mean concentration in the contaminated area is based on the random sample of women alone. It is identical to the mean in the sample of mothers.

difference in mean soil lead concentration (about 930 $\mu \mathrm{g} / \mathrm{g}$ ) suggests a rise in blood lead of about $0 \cdot 20 \mu \mathrm{M} / 1$ for $1000 \mu \mathrm{g} \mathrm{lead} / \mathrm{g}$ soil.

Within the control area the mean blood lead concentrations in the subsamples of women defined by vegetable consumption are homogeneous $(p>0.05)$. This fulfils expectations and implies no effect of the consumption of home grown vegetables on blood lead concentrations in the control area.

Within the contaminated area there is significant heterogeneity between the vegetable consumption groups, and the blood lead concentrations show a gradient. This implies that, compared with those who ate no home grown produce, there is a $15 \%$ excess in the blood lead concentrations of those who ate some, and a $28 \%$ excess in the women, most of whose vegetable consumption had been home grown. Interestingly, even the women who ate no locally grown produce had a mean blood lead concentration that was $42 \%$ higher than the concentration in the control women (difference $0 \cdot 16 \pm 0.03 \mathrm{uM} / \mathrm{l}$ ). This implies that vegetable consumption can explain only part (perhaps about half) of the excess, compared with the controls, in the blood lead concentrations of the women with the highest consumption of local produce. Nevertheless, the difference between the weighted mean for all the women in the contaminated area $(0.57 \pm 0.02 \mu \mathrm{M} / \mathrm{l})$ and the mean for the women who ate little or no local produce $(0.54 \pm 0.03 \mu \mathrm{M} / 1)$ implies that the consumption of locally grown produce can have only a small effect $(0.03 \mu \mathrm{M} / \mathrm{l})$ on the population mean blood lead concentration equivalent to raising the population mean by about $5 \%$.

\section{Discussion}

The three most useful statistics in this study are the mean blood lead concentrations in a representative group of women living in a control village with low concentrations of lead in soil $(0.38 \pm 0.09 \mu \mathrm{M} / \mathrm{l})$, and the mean concentrations in representative groups of women living in the area contaminated by lead spoil who either ate no locally grown vegetables $(0.54 \pm 0.03 \mu \mathrm{M} / \mathrm{l})$ and women, most of whose vegetable consumption came from locally grown produce $(0.69 \pm 0.03 \mu \mathrm{M} / \mathrm{l})$. From the means in the last two we can estimate the effect of the consumption of vegetables grown in lead contaminated land and this represents an increment of $0.15 \pm 0.04(28 \%)$ in mean blood lead concentration. From the first two mean concentrations we can estimate the contribution from soil to blood lead of pathways other than locally grown vegetables. These appear to account for an increment of $0.16 \pm 0.03 \mu \mathrm{M} / 1(42 \%)$ in blood lead. These two estimates together suggest that pathways other than the consumption of local produce are at least as important a pathway for lead.

Elsewhere we have examined the amount of lead on the hands of residents in the two areas. ${ }^{10}$ In summary, using a "wet wipe" technique ${ }^{11}$ we found a $30 \%$ excess in the amount of lead on the hands of the women in the old lead mining villages, compared with the women in the control village, and a $50 \%$ excess in the amount of lead on the food preparation surfaces in their kitchens. In fact, although we attribute all the excess in blood lead concentration in the women who relied most on home grown produce to the consumption of this produce, some of the excess may have come from the handling of the contaminated soil and vegetables. On the other hand, while we did not measure outdoor air lead, indoor air lead concentrations were low in all the villages, indicating that direct inhalation of contaminated dust is not important.

Vegetables can therefore constitute a pathway for lead. Their potential is, however, limited by several mechanisms. Firstly, lead, and even more zinc, which usually occurs together with lead ores, is phytotoxic and plant growth is limited in polluted soil. Certain vegetables-for example, spinach and 
carrots-cannot be grown successfully in the Halkyn area, and some other vegetables and fruit grow very poorly. Secondly, lead tends to be chelated in plant roots and in the skin of root vegetables, ${ }^{11}$ and these parts are usually removed by peeling during preparation for consumption. Furthermore, in leaf vegetables such as cabbage, brussels sprouts, etc the outer leaves contain very much more lead than the inner leaves, ${ }^{8}$ but most of the former are discarded in the kitchen. Then the cooking of vegetables removes some of their lead content, ${ }^{8}$ though if the cooking water is consumed this lead can be absorbed. ${ }^{12}$

Clearly, the pathways between soil and blood are complex and whereas vegetables can constitute an important route they are certainly not the only route, nor in the population as a whole are they likely to represent a major pathway. As the two areas we studied were chosen to be as similar as possible, apart from soil lead concentrations, and as we have shown low air lead and water lead concentrations in both, a comparison of soil and blood lead concentrations in the two areas can give an estimate of the effect of all the soil to blood pathways. This represents an increment of approximately $0 \cdot 20 \mu \mathrm{M} / 1(4 \cdot 1 \mu \mathrm{g} / \mathrm{dl})$ in blood lead per $1000 \mu \mathrm{g} / \mathrm{g}$ soil lead. This figure is close to estimates made in other surveys. Barltrop et al reported an increase of $0.22 \mu \mathrm{M} / 1$ in blood lead per $1000 \mu \mathrm{g} / \mathrm{g}$ in soil lead. ${ }^{13}$ Duggan in a review of the relation between children's blood lead and soil or dust lead found the median increment in blood lead per $1000 \mu \mathrm{g} / \mathrm{g}$ soil or dust lead to be $0.24 \mu \mathrm{M} / 1 .{ }^{14}$ At the same time it is possible that the soil:blood relation is curvilinear and so this figure may be inappropriate at higher levels of soil lead.

\section{References}

${ }^{1}$ Department of Health and Social Security. Lead and health: the report of a working party. London: HMSO, 1980.

${ }^{2}$ Ministry of Agriculture, Fisheries and Food. Survey of lead in food. 2nd suppl report. Working party on the monitoring of foodstufs for heavy metals. 10th report. London: HMSO, 1982.

${ }^{3}$ Smart GA, Warrington M, Evans WH. The contribution of lead in water to dietary lead intakes. J Sci Food Agric 1981; 32: 129-33.

4 Chamberlain AC. Fallout of lead and uptake by crops. Atmospheric Environment 1983; 17: 693-706.

5 Jones LHP, Clement CR. Lead uptake by plants and its significance for animals. In: Haepple P, ed. Lead and the environment. London: Institute of British Petroleum, 1972.

${ }^{6}$ Davies BE, Roberts LJ. The distribution of heavy metal contaminated soils in north-east Clwyd, Wales. Water, Air, and Soil Pollution 1978; 9: 507-18.

${ }^{7}$ Davies BE, White HM. Trace elements in vegetables grown on soils contaminated by base metal mining. $J$ Plant Nutr 1981; 3: 387-96.

${ }^{8}$ Ministry of Agriculture, Fisheries and Food. Working party on the monitoring of foodstufs for heavy metals. 2nd report. Survey of lead in food. London: HMSO, 1972.

${ }^{\circ}$ Gallacher JEJ, Elwood PC, Phillips KM, Davies BE, Jones DT. The relationship between pica and blood lead in areas of differing lead exposure. Arch Dis Child (in press).

${ }^{10}$ Sayre JW, Charney E, Vostal J, Pless IB. House and hand dust as a potential source of childhood lead exposure. Am J Dis Child 1974; 127: 167-70.

${ }^{11}$ Davies BE, Crews HM. The contribution of heavy metals in potato peel to dietary intakes. Sci Total Environ (in press).

${ }^{12}$ Little P, Fleming RG, Heard MJ. Uptake of lead by vegetable foodstuffs during cooking. Sci Total Environ 1980; 17: 111-32.

${ }^{13}$ Barltrop D, Strehlow CD, Thornton I, Webb JS. Absorption of lead from dust and soil. Postgrad Med J 1975; 51: 801-4.

${ }^{14}$ Duggan MJ. Lead in urban dust: an assessment. Water, Air, and Soil Pollution 1980; 14: 309-21. 